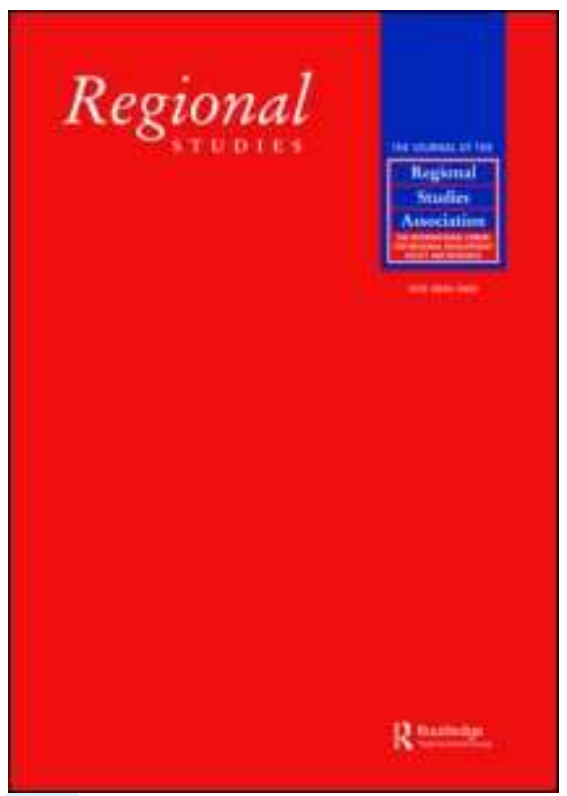

\title{
THE INTERNATIONALISATION OF PRODUCTION BY ITALIAN INDUSTRIAL DISTRICTS' FIRMS. STRUCTURAL AND BEHAVIOURAL DETERMINANTS
}

\begin{tabular}{|c|l|}
\hline Journal: & Regional Studies \\
\hline Manuscript ID: & CRES-2006-0117.R2 \\
\hline Manuscript Type: & Main Section \\
\hline JEL codes: & $\begin{array}{l}\text { F23 - Multinational Firms } \mid \text { International Business }<\text { F2 - } \\
\text { International Factor Movements and International Business }<\text { F - } \\
\text { Development, and Changes < R1 - General Regional Economics }<\text { R } \\
\text { - Urban, Rural, and Regional Economics, R15 - Econometric and } \\
\text { Input-Output Models } \mid \text { Other Models < R1 - General Regional } \\
\text { Economics < R - Urban, Rural, and Regional Economics }\end{array}$ \\
\hline Keywords: & $\begin{array}{l}\text { industrial districts, internationalisation of production, spillovers, } \\
\text { multinational corporations }\end{array}$ \\
\hline \hline
\end{tabular}

\section{SCHOLARONE Manuscripts}


1

2

3

4

5

6

7

8

9

The Internationalisation of Production by Italian Industrial Districts' Firms.

\title{
Structural and Behavioural Determinants
}

Formatted: English U.S.

\section{SERGIO MARIOTTI}

DIG-Politecnico di Milano, P.za L. da Vinci 32, 20133 Milano. E-mail:

sergio.mariotti@polimi.it

MARCO MUTINELLI

DIMI- University of Brescia, Via Branze 38, 25123 Brescia. E-mail:

marco.mutinelli@polimi.it

\section{LUCIA PISCITELLO}

DIG-Politecnico di Milano, P.za L. da Vinci 32, 20133 Milano. E-mail: lucia.piscitello@polimi.it

\begin{abstract}
The paper argues that structural and behavioural determinants combine to influence internationalisation of production through FDI by industrial districts' firms. As far as the former, leadership effects, represented by the presence of large firms within the district, and Porterian effects, denoted by the intensity of domestic rivalry, positively influence the likelihood that district firms will start internationalise through FDI. Moreover, spillovers induced by the presence of foreign-owned MNCs positively impact on the district's degree of internationalisation, provided it has already autonomously developed the ability to grow internationally. As far as behavioural features, previous export relationships increase the district firms' likelihood of undertaking FDI, while innovative capacity joins and strengthens internationalisation processes already started.
\end{abstract}


Key words: industrial districts, internationalisation of production, multinational corporations, spillovers

JEL: $\quad$ R110, R150, F230 


\section{INTRODUCTION}

The extensive literature on the Italian industrial districts ${ }^{1}$ has highlighted the esoteric array of interweaving factors that distinguished them as self-propelling and self-referential (that is, 'closed' in their set of production factors) systems: filière specialisation, network organisation, trust relations, collective learning, circulation of knowledge and technologies, diffuse entrepreneurship, spirit of emulation, quality, flexibility and mobility of human resources, education, strong domestic competition, and co-penetration between the economy and society in local cultures founded on centuries-long traditions (see PYKE et al. 1990, PYKE and SENGENBERGER 1992, COSSENTINO et al. 1996, BECATTINI et al. 2003, BECATTINI 2004). Over time, these factors have engendered Italian industrial districts' competitive advantages, and their strong propensity to export (BAGELLA et al., 1998; BECCHETTI and ROSSI, 2000; HELG, 2003).

However, such entirely local and self-contained entrepreneurial mechanisms have been recently threatened by the "international fragmentation of production" (FEENSTRA, 1998; ARNDT and KIERZKOWSKY, 2001; GEREFFI et al., 2005). Such a new industrial paradigm entails "global circuits of labour division" whereby firms' value chains are disarticulated, and the phases thus isolated are relocated internationally, emphasising crossborder linkages between firms in global production and distribution systems, rather than local linkages.

Cost advantages brought by these global value chains have highlighted several weaknesses in the district model: the fragility of the governance model and the organisational structure; lacks and deficiencies in innovation and advanced services, especially marketing, financial, and Internet-based activities; difficulties in absorbing and assimilating foreign technologies and in fulfilling the standards imposed - for both intermediate inputs and final goods - by the 
large international supply and purchasing chains; and scant resources to be devoted to extraordinary financing operations.

The new paradigm might force districts to undertake major changes in line with what STORPER (1997) has called the 'location paradox'. According to the latter, the advantages of local embeddedness, and the importance of local linkages, must be adjusted to new - and therefore risky - openness to international markets. Namely: (i) 'local networks' must become 'trans-local' networks spread internationally; (ii) these networks must be embedded in global supply and marketing circuits, where the market power of multinational companies generally prevail; and (iii) district firms must gain a more forceful presence as 'insiders' on broad international markets.

Although various forms, going from outsourcing to foreign direct investments (FDIs), and requiring different level of commitment, might be adopted to grow internationally, industrial districts do not adapt easily to the new paradigm. A first reason is the historically localised nature of their competitive advantages. The dependence of individual firms on idiosyncratic externalities constrains their locational choices. The integrated system of customers, suppliers, services, knowledge, and untraded interdependencies that has hitherto sustained districts is difficult to replicate abroad. The strong commercial culture (producing at home to sell on foreign markets) of districts' firms make them often reluctant to devote relevant resources to transferring their productive capacities to different and distant economic contexts. Furthermore, relocating production abroad requires organisational innovations often difficult for family small and medium enterprises (SMEs). Indeed, when suppliers are no longer geographically close, SMEs' resource constraints prevent their control over the whole production filière.

Within this context, the present paper aims to examine the determinants of the industrial firms' ability to internationalise their production. In particular, it suggests a conceptual 


\section{THE DETERMINANTS OF THE INTERNATIONAL GROWTH OF INDUSTRIAL DISTRICTS}

The literature on international growth by Italian industrial districts has mainly dealt with international trade (BAGELLA et al., 1998; BECCHETTI and ROSSI, 2000; HELG, 2003; MENGHINELLO, 2004; SHIN et al., 2006). Less attention has been paid to the internationalisation of production through either FDI or outsourcing that, according to the new paradigm previously mentioned, represent crucial drivers of their performance (MARIOTTI and MUTINELLI, 2004; CORÒ et al., 2005; FEDERICO, 2005).

In order to address such an issue, we elaborate a conceptual framework stemming from the literature on the industrial districts' international competitiveness and their determinants, which can be associated to structural and behavioural features of the districts themselves. Specifically, according with recent empirical studies on firms' international growth (SOUSA et al., 2000; GREENAWAY et al., 2004), we argue that these determinants might impact both on the firms' decision to undertake, and also on their decision about the extent of such an international involvement. 


\subsection{Structural determinants}

According to some scholars (LAZARSON and LORENZONI, 1999; LORENZONI and BADEN FULLER, 1995; BRIOSCHI et al., 2002; RUGMAN and VERBEKE, 2003), the district's likelihood of achieving international success depends on the presence of leader firms. Indeed, leader firms with high growth rates act are the engines of local industrial development as they generate innovation, enlarge and open new markets, and favour human capital spillovers. More importantly here, they also develop international production networks, and implement multinational market-seeking strategies. However, although the presence of leader firms may increase the likelihood that the district will undertake a virtuous internationalisation, their impact on the extent of such an international growth is less clear, especially vis-à-vis the other smaller firms dwelling the district. On the one hand, they may exert a pull effect by inducing the local firms linked with them to grow abroad (a sort of 'follow the customer' model); but on the other, they may act as a protective umbrella for those same firms, which may cut back their internationalisation efforts because the foreign initiatives already undertaken by the leaders provide the district with the needed international perspective. In this latter case, a substitution effect arises between the foreign investments made by leader firms and those by other firms in the district.

The Porterian school (PORTER, 1998, 2000; SAKAKIBARA and PORTER, 2001) takes a different approach by viewing vigorous 'local rivalry' as a crucial condition for international competitiveness. Competition on a local scale educates and trains firms in how they should compete internationally. It induces them to emulate successful strategies and models, and stimulates them to improve their performance by adopting more efficient production methods, also in their international dimension. Consequently, greater domestic competition boosts a district's international competitiveness and growth. According to this view, the polarisation of 
districts around one or more firms is deleterious. A district's excessive horizontal and vertical concentration dissolves domestic rivalry. It engenders inefficiencies and lock-ins due to a 'national champion syndrome', and it transforms non-core firms into passive sub-contractors, rather than specialised producers able to operate on world markets.

We claim that identifying success with one or the other structure would be misleading, as indeed neither conceptual nor empirical reasons recommend that one cluster structure is necessarily always more effective than the other one (the same perspective had been suggested for example by SAXENIAN, 1994). Our hypothesis is that the 'leadership' effect and the 'Porterian' one, coexist and combine, just as in innovation processes, 'Schumpeterian' effects (monopoly rewards innovative effort because it assures the appropriability of its outcomes) combine with 'Darwinian' ones (competition stimulates a search for differential competitive advantages). Therefore, the optimal trade-off between leadership and competitiveness in clusters is a matter to be decided in practice, not in theory.

A second important question risen within this debate concerns the role played by the affiliates of foreign-owned multinational corporations (MNCs) (for excellent recent surveys, see GÖRG and GREENAWAY, 2004; DRIFFIELD, 2006). Theoretical and empirical studies on growth envisage a positive relationship between the presence of foreign MNCs in a country and its endogenous development (BLOMSTRÖM et al., 2001; BALDWIN et al., 2005). Therefore, the presence of MNCs might provide a bridge to foreign markets for district's firms, as it injects a mix of skills, services and competitive stimuli into the district; it also increases, via both horizontal (i.e. intra-industry) and vertical (in customer/supplier relations) spillovers, the likelihood of systematic and fruitful external contacts by local firms. Moreover, it induces a more general kind of spillovers (that we call "lateral") related to the creation of a cosmopolitan atmosphere in the area, thereby reducing the danger of lock-ins and encouraging firms to seek growth paths different from the one dominant in the district. 
Conversely, relying on the dilemma risen by HYMER in his seminal work (HYMER, 1970), MNCs can represent an extensions of market power, other than an international vehicle of efficiency. Specifically, when foreign MNCs are deeply embedded in the local system (RODRIGUEZ-CLARE, 1996), and the links with district firms are intense, systematic and robust, the former participate in the district's growth and local firms benefit from their presence. However, MNCs may also unilaterally appropriate local knowledge and expertise (YOUNG et al., 1994; ENRIGHT, 2000; PHELPS et al., 2003; WHITE, 2004) or generate a “crowding out" or "competition" effect, stealing market share from less efficient indigenous firms (AITKEN and HARRISON, 1999), thus causing the district to decline and disintegrate. If this were the case, the impact of foreign MNCs' presence on the industrial district's international growth would be intuitively negative.

\subsection{Behavioural determinants}

Internationalisation performances of industrial districts depend also on the strategic behaviours of local firms.

First, a circular relationship has been envisaged between innovation and internationalisation. Innovation gives rise to proprietary advantages which enable firms to grow abroad and establish themselves on the relevant markets, capitalising the exclusive rents that derive therefrom (COOKE and MORGAN, 1998). In the case of districts, the innovativeness of firms is crucially determined by the endowment of scientific and technological infrastructures, and of the qualified localised capabilities that foster collective learning processes (MASKELL and MALMBERG, 1999; MARIOTTI and PISCITELLO, 2001).

At the same time, being multinational enhances the firm's innovative performance. Indeed, the presence on foreign markets stimulates the introduction of new processes and products, 


\section{THE EMPIRICAL ANALYSIS}

\subsection{Methodology}

and it also becomes a means to absorb 'localised expertise' that may be embedded and further developed within the home technological base (FROST, 2001).

Second, activities on foreign markets may generate important cognitive externalities that largely benefit the other district's firms. They favour accumulation of experience, which reduces the information costs needed to overcome the 'liability of foreignness' (ZAHEER, 1995). Moreover, relying on long-standing conceptual approaches (JOHANSON and VAHLNE, 1993), the market relationships established through exports and the relative commercial activities also help create the conditions - in terms of information, knowledge about foreign countries, global culture and managerial resources - to undertake major commitments and agreements with foreign companies (LIPSEY and WEISS, 1984; CANTWELL, 1994; MARKUSEN, 1995). As far as the latter, however, the relationship is complicated by the interaction of complementarity and substitution effects between exports and other forms of firms' internationalisation ${ }^{2}$ (see BLONINGEN, 2001; MARKUSEN, 2002; HELPMAN et al., 2004; GREENAWAY and KNELLER, 2005, for a survey). Specifically, if FDI substitutes previous export relationships, then we should expect a positive relationship between them; otherwise, when the former complements exports, the effect can not be predicted a priori.

Therefore, while previous exports should reasonably increase the likelihood that industrial districts undertake internationalisation through FDI, the net effect on the latter's extent is far from being univocally determined. 
The industrial district is not a collection of atomistic and autonomous producers, but a complex network of social relationships within and between firms and between firms and local institutions (SAXENIAN, 1994). Accordingly, each firm takes strategic decisions strictly interacting with other firms, both through implicit local arm's length transactions, and through explicit coordination. Moreover, incentives for coordinating foreign investments are provided by industrial policies, which also promote the internationalisation of the district as a whole $^{3}$ (for a survey on cluster policies around the world, see ANDERSSON et al., 2004).

Within this context, one should model the single firm's decision allowing for all the strategic interdependencies among firms (for an analysis of the influence of inter-firm relations on the strategies of the individual firm, see CANINA et al. 2005). Arguably, such a way is hardly feasible as it would require in depth analyses and detailed case studies. As a second best, we model the districts' firm international growth using the whole district as the unit of analysis in order to encompass the strategic interdependencies among district's firms. Additionally, we try to model part of the strategic interactions between district's firms, by disentangling the district's leader firms. That allows us to capture the impact of their international growth decision on the other companies' behaviour.

Internationalisation by industrial districts has been measured through FDI, which represents part of a more general strategy for internationalisation of production, often including outsourcing. Such a choice is justified first by the availability of data (see below), and secondly, by the fact that FDI has been acknowledged to be often complementary, rather than substitute, with the other forms of internationalisation. As far as the Italian case, such a complementarity has been tested by CUSUMANO et al. (2006) with reference to a sample of firms from Lombardy. Specifically, they show that being already abroad, especially through a subsidiary, increases the probability of developing linkages with local sub-contractors. However, MITRA and RANJAN (2005) show that complementarity stems from externalities 
generated by foreign MNCs on the host country; indeed, foreign MNCs stimulate local potential suppliers to improve their efficiency, thus increasing the former' resort to local outsourcing.

\subsection{Sources of data and descriptive statistics}

In order to identify the Italian industrial districts, we relied on the statistics issued by ISTAT, the Italian National Institute of Statistics, in 2002. ISTAT's method consists, first, in decomposing the national territory into local labour systems (LLS), which are identified on the basis of commuters' patterns and correspond to geographic areas wherein the majority of the resident population both live and work. Second, industrial districts are built by aggregating LLS by means of specific indicators (degree of industrialisation, presence of SMEs, production specialisation). The industrial districts thus identified amount to 199, classified in 10 macro sectors.

Our empirical analysis refers to these 199 districts, but their sectoral specialisation has been further detailed in order to better capture their productive scope on the one hand, while maintaining the diversification of district firms along filiere, on the other. Specifically, we considered a two-digit - or more - ATECO sectoral disaggregation, which led us to consider $17 \operatorname{sectors}^{5}$ (see Table 1).

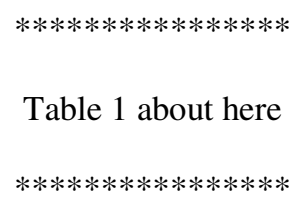

Table 1 shows the distribution by sector and geographical area of the 199 industrial districts considered. From the sectoral point of view, the so-called 'Made in Italy' sectors confirm their preponderant weight, accounting for $65.8 \%$ of the total. If we consider also the scale 
intensive and medium-tech manufacturing sectors, which we call here Intermediate sectors, the proportion rises to $88.9 \%$, while High-tech sectors account for a marginal $12.1 \%$.

Additionally, looking at the geographical dimension, a number of area specialisations do emerge: the North-West reveals an above-average number of districts specialised in Textiles and clothing, Machinery and equipment, Food and beverages, and Metal products; as far as the North-East, Wood and furniture, Machinery and equipments, Precision instruments and Non-metallic mineral products. Districts specialised in Leather and Footwear prevail in the Centre and in the South, while districts specialised in Food and beverages dominate in the South.

Data on the internationalisation of industrial districts via FDI, come from the Reprint database, which has been compiled by the Politecnico di Milano and sponsored by the Italian Institute for International Trade (ICE). The data set Reprint provides a census on both the foreign affiliates of Italian firms, and on Italian affiliates of foreign firms (in terms of number of employees and sales) since 1986, and it is yearly updated (for details see MARIOTTI and MUTINELLI, 2005).

As far as industrial district's degree of outward internationalisation, the Reprint data set allows to identify firms with foreign activities, whose headquarters is located in industrial districts. Table 2 illustrates the numbers and percentages of manufacturing firms with investments in foreign production activities and whose parent companies are located in industrial districts. The table shows both the total number and the majority-owned foreign affiliates. As at the beginning of 2003, 863 district firms owned 1,822 foreign (manufacturing) affiliates, for a total of 301,852 employees. The share on the outward internationalisation by the whole of Italian manufacturing industry is around one third of the total. As a benchmark for measurement of the phenomenon one could consider that the districts all together account for $44 \%$ of Italian manufacturing employment, and $46 \%$ of 
national manufacturing exports, which is comparable to their weight in terms of employment (ISTAT, 2002).

Hence, internationalised firms are under-represented in Italian districts. In other words, the gap in the internationalisation of production by industrial districts is as follows: the ratio between total employment by districts in manufacturing activities abroad and their domestic manufacturing employment is 0.148 (the ratio is 0.112 when only majority-owned affiliates are considered), while the ratio at the national level is $0.210(0.155)$.

However, these figures refer to all Italian-owned manufacturing firms in districts, independently of their sector. If one considers only firms whose main activity falls within a district's sector of specialisation, their number diminishes significantly but their degree of internationalisation is closer to the national average (20.5\% and $17.9 \%$ for the total and for the majority-owned case, respectively). Moreover, if the national average is calculated only considering the 17 district-level sectors of specialisation (therefore excluding sectors like automobiles and petrol), the comparison is even more favourable, for in this case the national average is $18.5 \%$ (for the total) and $16.1 \%$ (for majority-owned affiliates).

This latter evidence mitigates the negative judgement that might be drawn from the above information. However, the fact that districts are located in areas with a low presence of large industrial groups or other economic agents operating in sectors with greater international scope (mainly high-tech sectors) seemingly explains their lower degree of internationalisation. Yet districts comprise numerous national leaders in their respective sectors of specialisation whose internationalisation strategies closely reflect the national average. 
The main finding of the descriptive analysis is the existence of inter-district differences. As reported in Table 3, numerous districts (102 of the 199 ISTAT districts considered) had not foreign majority-owned affiliates ${ }^{6}$, as at the beginning of 2003.

$* * * * * * * * * * * * * * * *$

Table 3 about here

$* * * * * * * * * * * * * * * *$

Moreover, their degree of internationalisation (defined as the ratio between employment in majority-owned foreign affiliates of district firms and domestic employment in Italian-owned district firms) display a considerable heterogeneity (see Figure 1).

$* * * * * * * * * * * * * * * *$

Figure 1 about here

$* * * * * * * * * * * * * * * *$

\subsection{The model}

Our conceptual framework deals with the impact of structural and behavioural determinants on the district firms' internationalisation, meant as both the likelihood of undertaking international growth through FDI, and the extent of such a growth. The structure of such an issue contains an inherent sample selection problem: we do not observe firms' international involvement unless they have first started/attempted to internationalise. The standard statistical approach for treating this sort of problem is Heckman's (1979) two-stage methodology. Therefore, we estimate a first-stage selection equation of the probability that district firms start international growth, and then estimate a second-stage regression for the district firms' internationalisation degree, conditional on the results of the first-stage equation. Formally:

First stage: Selection equation of the probability/likelihood of internationalisation 
1

2

3

4

5

6

7

8

9

10

11

12

13

14

$$
\begin{gathered}
\mathrm{p}_{\mathrm{jk}}=\mathrm{Z}_{\mathrm{jk}} \gamma+\mathrm{v}_{\mathrm{jk}} \\
\mathrm{p}_{\mathrm{jk}}=1 \text { if } \mathrm{p}^{*_{\mathrm{jk}}}>0 \\
\mathrm{p}_{\mathrm{jk}}=0 \text { if } \mathrm{p}_{\mathrm{jk}}=0
\end{gathered}
$$

Second stage: Regression of district firms' internationalisation degree

$$
\mathrm{INT}_{\mathrm{jk}}=\mathrm{X}_{\mathrm{jk}} \beta+\mathrm{u}_{\mathrm{jk}} \text {, observed only if } \mathrm{p}_{\mathrm{jk}}=1
$$

The sample selection methodology helps to control for the possibility that the estimated coefficients for our structural and behavioural determinants in the internationalisation degree equation may be biased because some of the variables are observed only when district firms have decided to engage in FDI activity. This bias will occur if unobservable or unmeasured factors affect both the likelihood that firms start to internationalise and the results of such an attempt. If such unobserved factors are present, the error terms in the two equations will be correlated. This two-stage approach mitigates the potential problem that the coefficient estimates for structural and behavioural determinants might otherwise be interpreted as proxies for the likelihood that firms have started to internationalise through FDI. Instead, we explicitly estimate the probability that district firms have undertaken FDI prior to the estimation of the extent of such internationalisation.

\subsection{The dependent variables}

Given the nature of the model employed, we built two different dependent variables. Specifically:

(1) $\mathrm{D} \_\mathrm{INT} \mathrm{j}_{\mathrm{jk}}$ is a dummy variable that equals 1 if at least one firm in district $\mathrm{j}$, whose sector of specialisation is $\mathrm{k}$, controls foreign manufacturing activities in sector $\mathrm{k}$.

(2) $\mathrm{INT}_{\mathrm{jk}}$ is the degree of internationalisation of production for each district $\mathrm{j}$, whose sector of specialisation is k. Specifically, it has been measured as follows:

$\mathrm{INT}_{\mathrm{jk}}=\mathrm{EMPLfor}_{\mathrm{jk}} / \mathrm{EMPL}_{\mathrm{jk}}$, where: $\mathrm{j}=1, . ., 199$ and $\mathrm{k}=1, \ldots, 15$, 
EMPLfor $_{\mathrm{jk}}=$ number of employees in the majority-owned ${ }^{7}$ foreign manufacturing affiliates of firms located in district $\mathrm{j}$ in sector $\mathrm{k}$;

EMPL $_{\mathrm{jk}}=$ number of domestic employees in Italian-owned manufacturing firms located in district $\mathrm{j}$ in sector $\mathrm{k}$ (excluding the employees in foreign-owned firms).

In order to test our hypotheses on the leadership effect, the variable has been also calculated for the smaller district firms only i.e. those firms not belonging to the club of leaders (for the definition, see below). In this case, the variable becomes:

$\mathrm{INT}_{\mathrm{jk} \_} \mathrm{SME}=\left(\mathrm{EMPLfor}_{\mathrm{jk}}-\mathrm{EMPLfor} \_L e a d e r_{\mathrm{jk}}\right) /\left(\mathrm{EMPL}_{\mathrm{jk}}-\mathrm{EMPL}_{-}\right.$Leader $\left._{\mathrm{jk}}\right)$

\subsection{The explanatory variables}

The explanatory variables considered in the model refer to the conceptual framework illustrated in Section 2. Therefore, they have been classified as proxying structural and behavioural determinants of district firms' internationalisation. Descriptive statistics and correlation coefficients are illustrated in Table 4, while expected signs are reported in Table 5; further details (sources of data and years of reference) are given in the Appendix, in Table A1.

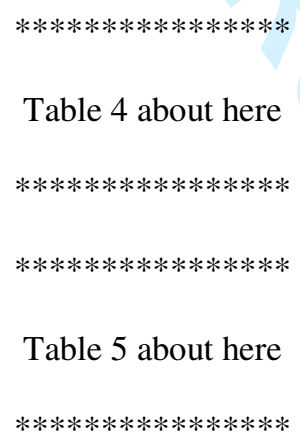

Table 5 about here

$* * * * * * * * * * * * * * * *$

\section{Structural determinants}

- The presence of leader firms in the district (variable 'Leader ${ }_{\mathrm{jk}}$ ') has been measured by the incidence of firms with more than 250 employees on the total number of firms in 
1

2

3

4

5

6

7

8

9

10

11

12

13

14

15

16

17

18

19

20

21

22

23

24

25

26

27

28

29

30

31

32

33

34

35

36

37

38

39

40

41

42

43

44

45

46

47

48

49

50

51

52

53

54

55

56

57

58

59

60

the district $\mathrm{j}$ and in the sector of specialisation $\mathrm{k}$. Although the proxy may appear rather crude as the prerogative of leaders is not deterministically associable with size, they are likely to have gained such a position because of their greater capacity to grow. Accordingly, and also relying on certain anecdotal evidence on the Italian case (e.g. FORTIS, 1998; CHIARVESIO et al., 2003), leader firms are unlikely to fall below a reasonably high size threshold. As far as the latter, we refer to the EU Commission Recommendation concerning the definition of dimensional classes for enterprises ${ }^{8}$.

According to our conceptual framework, we expect Leader to impact positively on the probability that district firms start international growth, while we do not have any a priori expectation as far as the impact on their internationalisation degree.

- The role of the leader firms in the district's internationalisation was measured by introducing the variable Int_leader ${ }_{\mathrm{j} k}$, defined as follows:

Int_Leader ${ }_{j k}=$ EMPLfor_Leader ${ }_{\mathrm{j} k} /$ EMPL_Leader $_{\mathrm{jk}}$

where:

EMPLfor_Leader $_{\mathrm{jk}}=$ number of employees in foreign manufacturing affiliates of leader firms in district $\mathrm{j}$ in sector $\mathrm{k}$;

EMPL_Leader $\mathrm{j}_{\mathrm{jk}}=$ number of employees in the (Italy-based) leader firms located in district $\mathrm{j}$ in sector $\mathrm{k}$.

Such a variable aims at testing whether the internationalisation of leader firms exerts a pull rather than substitution effect on the international growth of the other firms in the district. Accordingly, we do not have any a priori expectation on its estimated sign.

- The degree of domestic rivalry within the district has been measured, as in previous empirical studies (for a critical survey see SAKAKIBARA and PORTER, 2001), by concentration measures, which are obviously inverse measures of that. In particular, we used the Herfindahl index calculated in the district j's sector of specialisation k: 


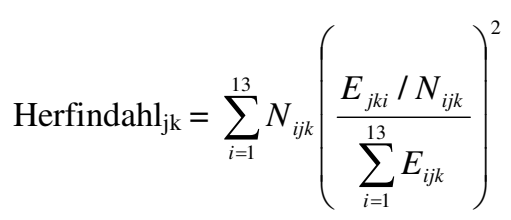

where: $\mathrm{i}=1, \ldots ., 13$ are the ISTAT employee classes;

$\mathrm{N}_{\mathrm{ijk}}$ is the number of firms belonging to class $\mathrm{i}$, in district $\mathrm{j}$ and sector of specialisation $\mathrm{k}$;

$\mathrm{E}_{\mathrm{i}}$ is the number of employees in class $\mathrm{i}$, in district $\mathrm{j}$ and sector of specialisation $\mathrm{k}$.

As we expect the degree of domestic rivalry to impact positively on the districts' firms internationalisation, Herfindhal should show a negative estimated sign.

- The presence of foreign MNCs has been captured by two variables intended to allow for two different aspects of inward FDI:

- MNC_spec $\mathrm{jk}_{\mathrm{jk}}$ measures the presence of foreign MNCs, in terms of employees, in the district's sector of specialisation $\mathrm{k}$, with reference both to the manufacturing sector and to the commercial and service sectors connected with it'. As the district's sector of specialisation has been defined in order to capture the whole industrial filiére, this variable accounts for both the potential horizontal and vertical spillover effects on the district's specific activities;

- MNC_lat $\mathrm{j}_{\mathrm{j}-\mathrm{k}}$ measures the presence of foreign MNCs in other sectors (with respect to the district's sector of specialisation, $\mathrm{k}$ ) in terms of employees. This variable takes account of the lateral spillover effects generated by foreign MNCs that are external to the district's sector of specialisation.

According with our conceptual framework, spillovers might reveal both positive and negative effects on the local context. Therefore, we do not have any a priori expectation on the estimated coefficients neither for MNC_spec nor for MNC_lat.

\section{Behavioural determinants}




\section{Control variables}

The analysis includes several controls for factors that may affect the district firms' international growth through FDI. First, in order to take into account the general economic conditions of the district areas, we added a proxy for the local economic, social and cultural development ${ }^{11}$. We expect that districts localised in more advanced areas might benefit from additional externalities and services (due, for instance, to the proximity to important urban 
centres) that increase their attitude towards international growth. Likewise, we considered also a dummy for districts localised in the Northern areas, in order to allow for advantages related both to the proximity to relevant host countries (namely, Western and Eastern Europe), and to the greater availability of network infrastructures that make it easier the access also to distant markets.

Finally, the list concludes with two sectoral dummies controlling for sectors more interested by internationalisation. Specifically, the first dummy (Advanced) refers to technologically advanced sectors, which are generally reported in the literature as being more involved in internationalisation processes (e.g. HATZICHRONOGLOU, 1999); the second one (Made in Italy) refers instead to sectors where Italian firms enjoy a traditional comparative advantage ${ }^{12}$ (as measured, for example, by revealed comparative advantage, see PIETROBELLI, 2002 and DE BENEDICTIS, 2005). The list of sectors considered refers to the classification reported in Table 1.

\section{THE RESULTS}

Table 6 reports the econometric estimates obtained for both the first stage, i.e the sample selection (columns a and c) and the second stage, i.e. the regressions of the district firms' internationalisation degree (columns $\mathrm{b}$ and $\mathrm{d}$ ). Specifically, columns $\mathrm{a}$ and $\mathrm{b}$ concern the totality of district firms, while columns $\mathrm{c}$ and d refer to the models run in order to test the leadership effect (and, therefore, run only on the smaller district firms). Table A2 in the Appendix reports the baseline probit and truncated regressions without correction for sample selection. The results with and without correction are very similar ${ }^{13}$.

$* * * * * * * * * * * * * * * *$

Table 6 about here 
1

2

3

As far as structural determinants are concerned, the presence of large leader firms increases significantly the likelihood that district firms' start internationalisation through FDI (the variable Leader shows, indeed, a positive coefficient that is significantly different from zero, at $\mathrm{p}<.01$ in the probit model, column a). Likewise, an internal robust domestic competition seems to be effective in training local companies and enabling them to grow internationally (the variable Herfindhal shows an estimated coefficient that is negative and significantly different from zero at $\mathrm{p}<.01)$. However, when leader firms are directly involved in international activities, they hinder the other (smaller) companies' international commitment (the variable Int_leader shows a negative estimated coefficient and strong statistical significance, at $\mathrm{p}<.05$, in column $\mathrm{d}$ ). The international perspective thus created seems to suffice the latter, which then reduce their efforts to invest abroad. In other words, a substitution effect between the foreign investments undertaken by the leaders and those by other firms in the district, does prevail on the pull effect.

Our hypothesis is then confirmed as these results suggest that 'leadership' and 'Porterian' effects interact virtuously to guarantee a sound international growth to the district. Relying only on the few leaders' international moves might eventually constrain the other district firms' international openness, as they might end to passively benefit from the formers' international growth, not developing any autonomous ability of growing abroad. Therefore, the co-existence of large customer firms and smaller supplier companies, which both cooperate and compete, seems to represent the most effective configuration to favour the district's answer to the mentioned paradigm of the international fragmentation of production. Within this context, the presence of foreign MNCs shows a peculiar role. Indeed, MNCs do not exert any impact on the start of the international growth by industrial district's firms, while they boost the latter's internationalisation degree, once it started (with $\mathrm{p}<.01$ ). In other 
words, spillovers from MNCs advantage only districts firms that have developed their own absorptive capacity through autonomous ability to grow internationally. That seems to hold especially when foreign MNCs belong to the district's sector of specialisation, thus revealing positive intra-industry spillovers. Indeed, according with the existing literature (AITKEN and HARRISON, 1999), these spillovers generally exert a negative competition effect on local companies (possibly captured by the negative, although not significant, sign in colum a), which hardly manage to start international growth processes. Therefore, the benefits stemming from the presence of foreign MNCs take off only once the district has already started international initiative. The same holds when considering what we have called "lateral" spillovers, i.e. those related to the creation of an international atmosphere in the district area. Indeed, they do not seem to be strong enough to trigger district firms' international growth, while contributing to strengthen it once started. Such a positive role does emerge especially when modelling the smaller district firms companies, which seem to benefit more from MNCs' presence (the variable MNC_lat is positive and highly significantly different from zero, at $\mathrm{p}<.01$, in column $\mathrm{d}$ ). Indeed, district's firms reduce cognitive asymmetries with the foreign MNCs, and can therefore face them, through imitation, learning, and cooperative relationships (CANTWELL, 1989; KOKKO, 1994; CASTELLANI and ZANFEI, 2003).

We are aware that more reliable evidence on the matter should allow for the effective embeddedness of foreign MNCs in the local system, rather then only the mere presence. However, such a measurement, which constitutes a rather difficult task per se (PHELPS et al., 2003), goes well beyond the scope of this paper.

As far as behavioural determinants are concerned, the openness of the industrial district to international trade appears to explain the likelihood of starting internationalisation of production through FDI. In particular, the district's firms attitude to export upon foreign 
markets appear to positively and significantly impact their ability to undertake FDI (the variable Export is positive and significant at $\mathrm{p}<.05$ and $\mathrm{p}<.10$ in columns a and $\mathrm{c}$, respectively), thus confirming our expectations. In fact, previous export relationships do not show any correlation with the internationalisation degree, thus confirming an underlying complex relationships. Only modelling the intertemporal relationships between exports and outward FDI in the same destination country could reveal the complementary and/or substitutive nature of such a relationship.

Likewise, the innovative activity conducted within the districts, which should forge their companies' competitive advantages, does not seem to be able to trigger the industrial district's international growth (the variable Innovation is positive but never significantly different from zero in the first stages of the model, see columns a and c). In other words, product and process innovations reached within the district, although promoting district firms' international competitiveness (via exports, for example), do not engender those favourable advantages and conditions that, alone, might start their internationalisation processes through FDI. However, innovation virtuously impacts on the international growth degree once it started. Indeed, existing foreign initiatives might foster innovative solutions which are better tailored on these markets' needs (SALOMON and SHAVER, 2005), which in turn positively influences the degree of foreign involvement.

As far as the experience already acquired abroad by district's firms, it is not significantly different from zero. In fact, although we expected that the relevant mechanisms of information and knowledge accumulation affect district firms, by increasing their confidence in foreign markets and fostering their greater involvement in foreign investment, the result does not come out as too much surprising, given the poorness of the proxy employed $(\text { Experience })^{13 .}$. 
Finally, as far as control dummies are concerned, both the "Made in Italy" and the Advantaged sectors are significantly important in increasing the probability that a district will start international growth. Advantaged sectors show also a positive impact on the extent of such an international growth for smaller firms.

The lack of statistical significance for geographical dummies shows that industrial districts' firms do not stem any advantage (as far as their international growth is concerned) from their location.

\section{CONCLUSIONS}

The conceptual framework developed to explain internationalisation of production by industrial districts' firms relies on both structural and behavioural determinants. The econometric model developed for this purpose yielded a number of statistically robust results. As far as structural factors, 'Leadership' effects, represented by the presence of large firms, and 'Porterian' ones, described by the intensity of domestic rivalry, combine to increase the likelihood that districts will internationalise. Moreover, the leadership of large firms exerts a composite effect on the degree of internationalisation of other (non leader) district firms. It increases the range of foreign growth opportunities available to smaller firms, but it eventually leads to a prevalent substitution effect: the internationalisation of large firms prompts an inertial behaviour by the other (smaller) firms, which do not develop any independent ability to grow internationally. The presence of affiliates of foreign-owned MNCs favours internationalisation by district's firms, but only once they have already maturated an adequate absorptive capacity, thanks for example to competencies autonomously developed on foreign markets. Foreign MNCs are presumably more influential, 
the greater their embeddedness in the district system - but this is an aspect which requires further research.

As far as behavioural determinants, other district performances seem to be positively correlated with the internationalisation of production. This applies to the innovativeness of districts, as measured by the intensity of patent registration by local firms, which positively influences their internationalisation degree. Likewise, the export performance of the district triggers the start up of internationalisation processes, replicating the sequential causation model (exports $\rightarrow$ commercial affiliates $\rightarrow$ productive affiliates). Previous export relationships do not show, instead, any impact on the district firms' degree of internationalisation, thus confirming the difficulties of capturing complex inter temporal linkages between export and FDI. In fact, these linkages would deserve further investigation (for example on the distinction between horizontal and vertical investments, on the one hand, and on the distinction between intra- and inter-firm trade, on the other) which goes beyond the scope of the present paper.

We then conclude with two general considerations. The foregoing analysis suggests that it would be advisable to discard - at the levels of both interpretation and policy-making - an undifferentiated conception of 'district'. In fact, districts have been shown to be highly heterogeneous, with marked structural and behavioural differences which significantly influence their current performances and their potential for future growth. In industrial policy terms, there is an undeniable necessity to act upon these determinants, which comprise genetic components intrinsic to the histories of districts. Consequently, it becomes important to move from a "national" to a "local" policy, and to adapt normative instruments and services supporting internationalisation to the distinctive features of each area.

The second general consideration concerns the agenda for future research, which appears quite rich. The specification of the model presented above should be improved by introducing 
more adequate measures of certain phenomena, also by defining the mechanisms of intradistrict interaction more precisely. Firstly, the notion of leader firm should be given more satisfactory operationalisation than that proposed here ('large district firm'). It does not seem, at least to our knowledge, that the literature contains a specification of the concept which enables, given well-known difficulties, its quantitative measurement. Secondly, further inquiry should seek to give better definition to the presence of foreign MNCs in a district. We refer in particular to the introduction of a proxy for the degree of embeddedness achieved through linkages with local actors and participation in the local community. Finally, further data are required to refine the analysis of the causality relations between foreign trade and FDI. The findings of this paper seem to justify greater research efforts in the directions indicated. 


\section{NOTES}

${ }^{1}$ Although in the recent literature the term cluster has increasingly gained favour, "the concept has now acquired such a variety of uses, connotations and meanings that is has, in many respects, become a chaotic concept" (for a critical review on the use of the concept of cluster, see MARTIN and SUNLEY, 2003, pp. 9-10). For this reason, we prefer the term industrial district, for which a much more largely shared Marshallian definition does exist (BECATTINI, 2004).

${ }^{2}$ Specifically, FDI undertaken for market-seeking purposes, and to replicate the parent company's activities abroad, have export substitution effects. The linkage is more complex when FDI is mainly resource-seeking, as it often generates both intra- and inter-industry flows of exports and imports.

3 The rationale is that in SME dominated economies (like Italy), the size of firms prevents or reduces the possibility to count on firm-based international growth strategies. Therefore, a solution is to push forward the internationalisation of clusters: domestic firms could in that way pursue collective internationalisation processes, strengthening their internal relationships and implementing new international linkages.

${ }^{4}$ Such a classification has unquestionable advantages, mainly related to the fact that its territorial exhaustiveness and identification of precisely circumscribed spaces enables analysis to be conducted on quantitative indicators (population, firms, employees, etc.) homogeneous across all districts. The other available classifications (see, for example, IPI, 2002) rely on disomogeneous, and often subjective, criteria. ${ }^{5}$ Specifically, we found inappropriate keeping classifications that are too broad. In particular, in cases like Mechanicals, several specialisations might be easily disentangled (Processing of metals, Metal products, Machinery and equipments, Electronics and electrical apparatus). We acknowledge that such a method might miss some fringe segments along the filiere (for example when a district specialised in Textile has developed competencies also in Textile Machinery). However, the issue remains unsolved even in the (broader) ISTAT classification.

${ }^{6}$ It should be pointed that the phenomenon is evolving rapidly. Moreover, as in all diffusive processes, reference to the time period in which both sub-sets (internationalised and non-internationalised districts) are of ample size is important for study of the phenomenon's determinants.

${ }^{7}$ There were two reasons for referring only to majority-owned foreign affiliates: (i) the volatile nature of minority-owned ones; (ii) without adopting arbitrary procedures, it is not possible to apply a single measure to employees in majority shareholdings and the employees of foreign activities which may be of substantial size but in which there are minority shareholdings of very small proportions. 
${ }^{8}$ Specifically, the EU Commission Recommendation of 6 May 2003 put forward the definition of micro, small and medium-sized enterprises (SMEs) as being made up of enterprises which employ fewer than 250 persons.

${ }^{9}$ For example, if the district is specialised in textiles/clothing, consideration was made of both the foreign multinationals undertaking production in the above-mentioned manufacturing sector and the multinationals explicitly connected with it: affiliates with commercial activities concerning textiles and clothing, affiliates furnishing services connected with them (e.g. consultancy, logistics, dedicated computer and software).

${ }^{10}$ These data were made available by the CRENoS-Centro Ricerche Economiche Nord Sud. We wish to thank Stefano Usai and Barbara Dettori, in particular, for their valuable assistance.

${ }^{11}$ It is worth observing that such an indicator is available at the NUTS 3 level (corresponding to the Italian provinces).

${ }^{12}$ It is worth observing that Machinery and equipments, which has been classified as Advanced, enjoys also comparative advantages.

${ }^{13}$ If the correlation between the residuals in the first and second stage regressions in the sample selection model is not significantly different from zero, sample selection does not bias the coefficients in the regression of the internationalisation degree. Table 6 indicates that this correlation (i.e. the Inverse Mill's ratio) is not significant from zero for the full sample of firms, while it is not for the sub sample of the smaller firms dwelling the districts. However, we retain the sample selection approach for the remainder of the analysis also for the full sample, as a cautionary measure.

${ }^{14}$ It might be not out of place here to observe that we tried alternative proxies for experience (e.g. the age of the first FDI). However, none of these revealed any significance. 
1

2

3

4

5

6

7

8

9

\section{REFERENCES}

AITKEN B.J. and HARRISON A.E. (1999) Do domestic firms benefit from direct foreign investment? Evidence from Venezuela, American Economic Review 89, 605-618.

ANDERSSON T., SCHWAAG SERGER S., SÖRVIK J. and WISE HANSSON E. (2004), The Cluster Policies Whitebook, Iked, Malmö.

ARNDT S.W. and KIERZKOWSKY H. (Eds) (2001) Fragmentation. New Production Patterns in the World Economy. Oxford University Press, Oxford.

BALDWIN R.E., BRACONIER H. and FORSLID R. (2005) Multinationals, endogenous growth, and technological spillovers: Theory and evidence, Review of International Economics, 13, 945-963.

BECATTINI G. (2004) Industrial Districts. A New Approach to Industrial Change. Edward Elgar, Cheltenham.

BECATTINI G., BELLANDI M., DEI OTTATI G. and SFORZI F. (2003) From Industrial Districts to Local Development. An Itinerary of Research. Edward Elgar, Cheltenham.

BECCHETTI L. and ROSSI S.P.S. (2000) The positive effect of industrial district on the export performance of Italian firms, Review of Industrial Organization 16, 53-68.

BLOMSTRÖM M., FORS G. and LIPSEY R.E. (1997) Foreign direct investment and employment: Home country experience in the United States and Sweden, Economic Journal 107, 1787-1797.

BLOMSTRÖM M., GLOBERMAN S. and KOKKO A. (2001) The determinants of host country spillovers from foreign direct investment: Review and synthesis of the literature, in PAIN N. (Ed) Inward Investment, Technological Change and Growth. Palgrave MacMillan, New York.

BLONIGEN B.A. (2001) In search of substitution between foreign production and exports, 
Journal of International Economics 53, 81-104.

BRIOSCHI F., BRIOSCHI M.S. and CAINELLI G. (2002) From the industrial district to the district group: An insight into the evolution of local capitalism in Italy, Regional Studies 36, 1037-1053.

CANINA L., ENZ C.A. and HARRISON J.S. (2005) Agglomeration effects and strategic orientations: Evidence from the US lodging industry, Academy of Management Journal 48, $565-581$.

CANTWELL J.A. (1994) The relationship between international trade and international production, in GREENAWAY D. and WINTERS L. A. (Eds) Surveys in International Trade. Backwell, Oxford UK and Cambridge USA.

CASTELLANI D. and ZANFEI A. (2003) Technology gaps, absorptive capacity and the impact of inward investments on productivity of European firms, Economics of Innovation and New Technology 12, 555-576.

CHIARVESIO M., DI MARIA E. and MICELLI S. (2003) Processi di internazionalizzazione e strategie delle imprese distrettuali, Economia e società regionale 1, 68-107

COOKE P. and MORGAN K. (1998) The Associational Economy: Firms, Regions, and Innovation. Oxford University Press, Oxford.

CORÒ G., VOLPE M. and BONALDO S. (2005), Local Production Systems in Italy between Fragmentation and International Integration, Incontro di Studio del Gruppo CNR su Economia Internazionale e Sviluppo, "Investimenti diretti esteri, commercio internazionale e competitività”, 27-28 May 2005, Università degli Studi di Urbino.

COSSENTINO F., PYKE F. and SENGENBERGER W. (Eds) (1996) Local and Regional Response to Global Pressure: The case of Italy and its Industrial Districts, International Institute for Labour Studies, Geneva.

DE BENEDICTIS L. (2005) Three decades of Italian comparative advantages, The World 
1

Economy 28, 1679-1709.

DRIFFIELD N. (2006) On the search for spillovers from foreign direct investment (FDI) with spatial dependence, Regional Studies 40, 107-119.

ENRIGHT M.J. (2000) Regional clusters and multinational enterprises: Independence, dependence or interdependence? International Studies of Management and Organisation 30, $114-138$.

FEDERICO S. (2005) The internationalization of production and industrial districts: An analysis of Italy's foreign direct investments, in SIGNORINI L.F. (Ed), Local Economies and Internationalization in Italy, pp. 313-342, Banca d'Italia, Roma.

FEENSTRA R.C. (1998) Integration of trade and disintegration of production in the global economy, Journal of Economic Perspective 12, 31-50.

FORTIS M. (1998) Il Made in Italy, Il Mulino, Bologna.

FROST T.S. (2001) The geography sources of foreign subsidiaries' innovation, Strategic Management Journal 22, 101-123.

GEREFFI G., HUMPHREY J. and STURGEON T. (2005) The governance of global value chains, Review of International Political Economy 12, 78-104.

GÖRG H. and GREENAWAY D. (2004) Much ado about nothing? Do domestic firms really benefit from foreign direct investment? World Bank Research Observer 19, 171-197.

GREENAWAY D., SOUSA N. and WAKELIN K. (2004) Do domestic firms learn to export from multinationals?, European Journal of Political Economy 20, 1027-1043.

GREENAWAY D. and KNELLER R. (2005) Firm heterogeneity, exporting and foreign direct investment: A survey, GEP working paper No. 32, Leverhulme Centre, Nottingham. HATZICHRONOGLOU T. (1999) The globalisation of industry in OECD countries. Science, Technology and Industry Working Papers No. 2, OECD, Paris .

HELG R. (2003) Italian district in the international economy, in DI MATTEO M. and 
PIACENTINI P. (Eds) The Italian Economy at the Dawn of the XXI Century, Aldershot,

Ashgate.

HELPMAN E., MELITZ M.J. and YEAPLE S.R. (2004) Export versus FDI with heterogeneous firms, American Economic Review 94, 300-316.

HYMER S.H. (1970) The efficiency (contradictions) of multinational corporations, American Economic Review 60, 441-448.

IPI (2002) L'esperienza italiana dei distretti industriali, Istituto per la Promozione Industriale, Ministero delle Attività Produttive, Rome.

ISTAT (2002) Le esportazioni dai sistemi locali del lavoro, Collana Argomenti, No. 22. Istat, Rome.

JOHANSON J. and VAHLNE J.E. (1993) The internationalisation process of the firm. A model of knowledge development and increasing foreign commitments, in BUCKLEY P. and GHAURI P. (Eds) The internationalisation of the firm. Academic Press, London.

LAZERSON M. and LORENZONI G. (1999) Resisting organizational inertia: The evolution of industrial districts,Journal of Management and Governance 3, 361-377.

LIPSEY R.E. and WEISS M.Y. (1984) Foreign production and exports of individual firms, Review of Economics and Statistics 66, 304-308.

LORENZONI G. and BADEN-FULLER C. (1995) Creating a strategic center to manage a web of partners, California Management Review 37, 146-163.

MARIOTTI S. and MUTINELLI M. (2004) Small multinational groups in the Italian industrial district: Interpretations and empirical evidence from the mechanical engineering industry, in CAINELLI G. and ZOBOLI R. (Eds) The evolution of industrial districts. Changing governance, innovation and internationalisation of local capitalism in Italy, pp. 336-347. Physica-Verlag, Heidelberg. 
1

MARIOTTI S. and MUTINELLI M. (2005) Italia Multinazionale 2004. Le partecipazioni italiane all'estero e estere in Italia. Rubbettino, Soveria Mannelli.

MARIOTTI S. and PISCITELLO L. (2001) Localised capabilities and internationalisation of manufacturing activities by SMEs, Entrepreneurship and Regional Development 13, 6580.

MARKUSEN J.R. (1995) The boundaries of multinational enterprises and the theory of international trade, Journal of Economic Perspectives 9, 169-189.

MARKUSEN J.R. (2002) Multinational Firms and the Theory of International Trade. MIT Press, Cambridge.

MARTIN R. and SUNLEY P. (2003) Deconstructing clusters: chaotic concept or policy panacea? Journal of Economic Geography 3, 5-35.

MASKELL P. and MALMBERG A. (1999) Localised learning and industrial competitiveness, Cambridge Journal of Economics 23, 167-185.

MENGHINELLO S. (2004), Local engines of global trade: The case of Italian industrial districts, in CAINELLI G. and R. ZOBOLI (Eds) The Evolution of Industrial Districts. Changing Governance, Innovation, and Internationalisation of Local Capitalism in Italy, , pp. 319 - 335. Physica-Verlag, Heidelberg.

PHELPS N.A., MACKINNON D., STONE I. and BRAIDFORD P. (2003) Embedding the multinationals? Institutions and the development of overseas manufacturing affiliates in Wales and North East England, Regional Studies 37, 27-40.

PIETROBELLI C. (2002) La competitività dell'Italia nei confronti dei Paesi industrializzati: dinamiche settoriali e di mercato, in GALLI G. and L. PAGANETTO (Eds) La competitività dell'Italia: le imprese, , pp. 275-315. Il Sole 24Ore, Rome.

PHELPS N. A., MACKINNON D., STONE I. and BRAIDFORD P. (2003) Embedding the multinationals? Institutions and the development of overseas manufacturing affiliates in 
Wales and North East England, Regional Studies 37, 27-40.

PORTER M. (1998) Clusters and the new economics of competition, Harvard Business Review, November-December, 77-90.

PORTER M.E. (2000) Location, competition, and economic development: Local clusters in a global economy, Economic Development Quarterly 14, 15-34.

PYKE F., BECATTINI G. and SENGEMBERGER W. (Eds) (1990) Industrial Districts and Inter-firm Cooperation in Italy. International Institute for Labour Studies, Geneva.

PYKE F. and SENGEMBERGER W. (Eds) (1992) Industrial Districts and Local Economic Regeneration. International Institute for Labour Studies, Geneva.

RODRIGUEZ-CLARE A. (1996) Multinationals, linkages and economic development, American Economic Review 86, 852-873.

RUGMAN A.M. and VERBEKE A. (2003) Multinational enterprises and clusters: An organising framework, Management International Review 43, 151-169.

SAKAKIBARA M. and Porter M.E. (2001) Competing at home to win abroad: Evidence from Japanese industry, The Review of Economics and Statistics 83, 310-322.

SALOMON R.M., SHAVER J. M (2005) Learning by exporting: New insights from examining firm innovation, Journal of Economics and Management Strategy 14, 431-460.

SAXENIAN A. (1994) Regional Advantage: Culture and Competition in Silicon Valley and Route 128. Harvard University Press, Cambridge, MA.

SHIN M.E., AGNEW J., BREAU S. and RICHARDSON P. (2006) Place and the geography of Italian export performance”, European Urban and Regional Studies 13, 195-208.

SOUSA N., GREENAWAY D. and WAKELIN K. (2000) Multinationals and export spillovers, Centre for Research on Globalisation and Labour Market, Research paper No. 14, Nottingham.

STORPER M. (1997) The Regional World: Territorial Development in a Global Economy. 
1 
Table 1 - The sectoral and geographical distribution of Italian manufacturing districts 
Table 2 - The presence in Italian manufacturing districts of firms with foreign affiliates, $\underline{2003}$

\begin{tabular}{|c|c|c|c|c|}
\hline \multirow{2}{*}{$\underline{\text { Indicators }}$} & \multicolumn{2}{|c|}{ Total manufacturing } & \multicolumn{2}{|c|}{ Specialisation sectors } \\
\hline & $\underline{\text { Total }}$ & Majority & $\underline{\text { Total }}$ & Majority \\
\hline Investing firms (No.) & $\underline{863}$ & $\underline{693}$ & $\underline{336}$ & $\underline{285}$ \\
\hline$\%$ of national total & $\underline{31.2}$ & $\underline{31.7}$ & & \\
\hline Foreign affiliates (No.) & $\underline{1,822}$ & $\underline{1,432}$ & $\underline{861}$ & 691 \\
\hline$\%$ of national total & $\underline{36.1}$ & $\underline{35.5}$ & & \\
\hline Employees in foreign affiliates (No.) & $\underline{301,852}$ & $\underline{227,524}$ & $\underline{162,636}$ & $\underline{141,927}$ \\
\hline$\%$ of national total & $\underline{32.8}$ & $\underline{33.4}$ & & \\
\hline Degree of internationalisation (a) & & & & \\
\hline -industrial districts & $\underline{0.148}$ & $\underline{0.112}$ & $\underline{0.205}$ & $\underline{0.179}$ \\
\hline - Italy & $\underline{0.210}$ & $\underline{0.155}$ & $\underline{0.185}$ & $\underline{0.161}$ \\
\hline Note: & & & & \\
\hline
\end{tabular}


Table 3 - The internationalisation degree of Italian manufacturing districts

\begin{tabular}{lccc}
\hline$\underline{\text { Sector }}$ & $\begin{array}{l}\text { No. of } \\
\text { districts }\end{array}$ & $\begin{array}{c}\text { No. of districts } \\
\text { internationalised }\end{array}$ & $\underline{\text { Internationalisation }}$ \\
\hline degree (a)
\end{tabular}

(a) Ratio between employment in majority-owned foreign affiliates of district firms and domestic employment in Italian-owned district firms

(b) Such a value excludes the district of Parma where two large Italian-owned MNCs (Parmalat and Barilla) are located. Employment abroad by these two companies its more than two and half times the domestic one 


\section{Page 39 of 44}

\section{Regional Studies}

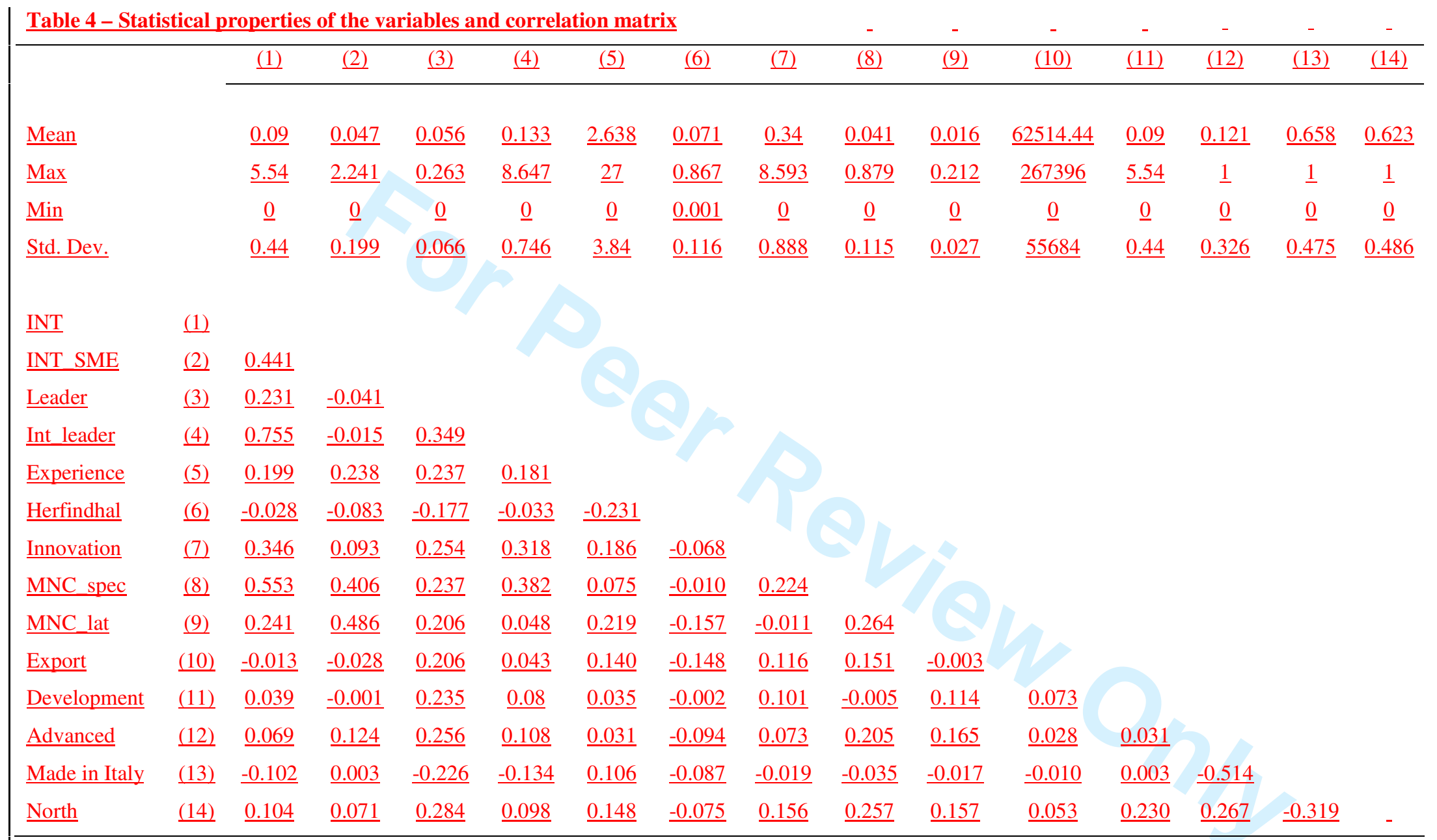

39

http://mc.manuscriptcentral.com/cres Email: regional.studies@fm.ru.nl 


\section{Table 5 - Expected signs for explanatory variables}

\begin{tabular}{cc}
\hline Selection equation & Regression of district's firms \\
(probability of internationalization) & internationalization degree
\end{tabular}

$\underline{\text { Structural }}$

Leader

Internat_leader (a)

Herfindhal

MNC_spec

$\underline{\text { MNC_lat }}$

Behavioural

Experience

$\underline{\text { Innovation }}$

Export

\section{$\underline{\text { Control }}$}

Development

North

Advanced

Made in Italy

$\underline{\text { Note }}$

(a): Included only in the model for INT_SMEs
Formatted: Font: $11 \mathrm{pt}$, Complex Script Font: $11 \mathrm{pt}$

\section{Formatted Table}

Formatted: Font: 11 pt, Complex Script Font: $11 \mathrm{pt}$

Formatted Table

Formatted: Font: $11 \mathrm{pt}$, Complex Script Font: 11 pt

Formatted Table 
Table 6 - Results of the econometric estimations, Heckman two-stage models

\begin{tabular}{|c|c|c|c|c|}
\hline & \multicolumn{2}{|c|}{$\underline{\text { INT }}$} & \multicolumn{2}{|c|}{ INT_SME } \\
\hline & Probit (a) & Truncated (b) & Probit (c) & Truncated (d) \\
\hline \multirow[t]{2}{*}{$\underline{\text { Constant }}$} & -2.942 & $\underline{-0.890}$ & -3.423 & $-1.963 *$ \\
\hline & $\underline{(-1.37)}$ & $\underline{(-0.65)}$ & $\underline{(-1.62)}$ & $\underline{(-1.76)}$ \\
\hline \multirow[t]{2}{*}{$\underline{\text { Leader }}$} & $\underline{6.259} * * *$ & $\underline{0.372}$ & $\underline{3.219} *$ & $\underline{0.310}$ \\
\hline & $\underline{(3.19)}$ & $\underline{(0.31)}$ & $\underline{(1.83)}$ & $\underline{(0.43)}$ \\
\hline \multirow[t]{2}{*}{$\underline{\text { Int_leader }}$} & & & & $-0.064 * *$ \\
\hline & & & & $\underline{(-2.56)}$ \\
\hline \multirow[t]{2}{*}{ Herfindhal } & $\underline{-5.808} * * *$ & $\underline{1.734}$ & $\underline{-7.098} * * *$ & $\underline{-3.046} *$ \\
\hline & $\underline{(-3.03)}$ & $\underline{(1.13)}$ & $\underline{(-3.30)}$ & $(-1.74)$ \\
\hline \multirow[t]{2}{*}{$\underline{\text { MNC_spec }}$} & $\underline{-0.139}$ & $\underline{3.414}$ **** & $\underline{0.869}$ & $\underline{1.594} * * *$ \\
\hline & $(-0.13)$ & $\underline{(8.58)}$ & $\underline{(0.85)}$ & $\underline{(5.00)}$ \\
\hline \multirow[t]{2}{*}{$\underline{\text { MNC lat }}$} & $\underline{4.975}$ & $\underline{-0.569}$ & $\underline{1.327}$ & $\underline{3.287} * * *$ \\
\hline & $(1.10)$ & $(-0.36)$ & $\underline{(0.33)}$ & $\underline{(3.90)}$ \\
\hline \multirow[t]{2}{*}{ Experience } & & $\underline{-0.003}$ & & $\underline{0.002}$ \\
\hline & & $\underline{(-0.30)}$ & & $\underline{(0.36)}$ \\
\hline \multirow[t]{2}{*}{ Innovation } & $\underline{0.157}$ & $\underline{0.088} * * *$ & $\underline{0.187}$ & $\underline{0.059} * *$ \\
\hline & $(0.92)$ & $(2.06)$ & $\underline{(1.13)}$ & $\underline{(2.07)}$ \\
\hline \multirow[t]{2}{*}{ Export } & $\underline{1.48 \mathrm{E}-05} * * *$ & $\underline{-1.63 \mathrm{E}-06}$ & $\underline{1.08 \mathrm{E}-05^{*}}$ & $\underline{2.26 \mathrm{E}-06}$ \\
\hline & $\underline{(2.57)}$ & $\underline{(-0.89)}$ & $\underline{(1.96)}$ & $\underline{(1.65)}$ \\
\hline \multirow[t]{2}{*}{ Development } & $\underline{0.003}$ & $\underline{-0.001}$ & $\underline{0.005}$ & $\underline{0.002}$ \\
\hline & $\underline{(0.70)}$ & $\underline{(-0.65)}$ & $\underline{(1.14)}$ & $\underline{(1.43)}$ \\
\hline \multirow[t]{2}{*}{ North } & $\underline{0.229}$ & $\underline{0.011}$ & $\underline{0.179}$ & $\underline{0.110}$ \\
\hline & $\underline{(0.94)}$ & $\underline{(0.09)}$ & $\underline{(0.74)}$ & $\underline{(1.48)}$ \\
\hline \multirow[t]{2}{*}{$\underline{\text { Advanced }}$} & $\underline{1.126} * * *$ & $\underline{-0.382}$ & $\underline{0.403}$ & $\underline{0.167}$ \\
\hline & $\underline{(2.77)}$ & $\underline{(-1.62)}$ & $\underline{(1.11)}$ & $\underline{(1.61)}$ \\
\hline \multirow[t]{2}{*}{$\underline{\text { Made in Italy }}$} & $\underline{0.758} * *$ & $\underline{-0.054}$ & $\underline{0.503} \underset{*}{*}$ & $\underline{0.274} * *$ \\
\hline & $\underline{(2.49)}$ & $\underline{(-0.26)}$ & $(1.68)$ & $\underline{(2.25)}$ \\
\hline Invmills & & $\frac{-1.147}{(0.65)}$ & & $\underline{\underline{0.628}} * * *$ \\
\hline \multirow[t]{2}{*}{$\underline{\text { Sigma }}$} & & 0.391 *** & & $-0.193 *$ \\
\hline & & $(13.93)$ & & $(-1.76)$ \\
\hline No. obs. & $\underline{199}$ & $\underline{97}$ & $\underline{199}$ & $\underline{85}$ \\
\hline No. Dependent $=1$ & $\underline{97}$ & & $\underline{85}$ & \\
\hline Log likelihood & $\underline{-98.033}$ & -46.672 & -107.393 & $\underline{19.219}$ \\
\hline LR chi2 & $\overline{79.68}$ & & $\underline{56.85}$ & \\
\hline Pseudo R-squared & $\overline{0.289}$ & & $\overline{0.209}$ & \\
\hline Wald chi2 & & $142.51 * * *$ & & $110.69 * * *$ \\
\hline
\end{tabular}


$\underline{\text { Table A1 - Sources of data for dependent and explanatory variables }}$

\begin{tabular}{|c|c|c|}
\hline & $\underline{\text { Source }}$ & Year \\
\hline & Dependent variable & \\
\hline \multirow[t]{3}{*}{$\underline{\text { Int }}$} & $\underline{\text { REPRINT data base }}$ & $\underline{2003}$ \\
\hline & ISTAT - Census Data & $\underline{2001}$ \\
\hline & $\underline{\text { Explanatory variables }}$ & \\
\hline \multicolumn{3}{|l|}{$\underline{\text { Structural }}$} \\
\hline$\underline{\text { Leader }}$ & $\underline{\text { ISTAT - Census Data }}$ & $\underline{2001}$ \\
\hline$\underline{\text { Int_leader }}$ & $\underline{\text { REPRINT data base }}$ & $\underline{2001}$ \\
\hline$\underline{\text { Herfindhal }}$ & ISTAT - Census Data & $\underline{2001}$ \\
\hline MNC_spec & $\underline{\text { REPRINT data base }}$ & $\underline{2001}$ \\
\hline$\underline{\text { MNC lat }}$ & $\underline{\text { REPRINT data base }}$ & $\underline{2001}$ \\
\hline \multicolumn{3}{|l|}{ Behavioural } \\
\hline Experience & $\underline{\text { REPRINT data base }}$ & $=$ \\
\hline Innovation & European Patent Office & $\underline{1995-1997}$ \\
\hline Export & $\underline{\text { ISTAT }}$ & $\underline{1996}$ \\
\hline \multicolumn{3}{|l|}{$\underline{\text { Control }}$} \\
\hline$\underline{\text { Development }}$ & Il Sole 24Ore & $\underline{2001}$ \\
\hline
\end{tabular}


Table A2 - Results of the econometric estimations, probit and truncated models

\begin{tabular}{|c|c|c|c|c|}
\hline & \multicolumn{2}{|l|}{ INT } & \multicolumn{2}{|c|}{ INT_SME } \\
\hline & Probit (a) & Truncated (b) & Probit (c) & Truncated (d) \\
\hline \multirow[t]{2}{*}{ Constant } & -2.942 & $\underline{0.530}$ & -3.423 & $\underline{-0.009}$ \\
\hline & $(-1.37)$ & $\underline{(0.50)}$ & $(-1.62)$ & $(-0.02)$ \\
\hline \multirow[t]{2}{*}{$\underline{\text { Leader }}$} & $\underline{6.259}$ *** & $\underline{0.805}$ & $\underline{3.219} *$ & $\underline{-0.907 * *}$ \\
\hline & $\underline{(3.19)}$ & $\underline{(1.22)}$ & $\underline{(1.83)}$ & $\underline{(-2.34)}$ \\
\hline \multirow[t]{2}{*}{$\underline{\text { Int_leader }}$} & & & & $\underline{-0.063} * *$ \\
\hline & & & & $\underline{(-2.48)}$ \\
\hline \multirow[t]{2}{*}{$\underline{\text { Herfindhal }}$} & $\underline{-5.808} * * *$ & $\underline{1.234}$ & $\underline{-7.098} * * * *$ & $\underline{0.218}$ \\
\hline & $\underline{(-3.03)}$ & $\underline{(1.27)}$ & $\underline{(-3.30)}$ & $\underline{(0.33)}$ \\
\hline \multirow[t]{2}{*}{ MNC_spec } & $\underline{-0.139}$ & $\underline{3.435} * * *$ & $\underline{0.869}$ & $1.160 * * *$ \\
\hline & $\underline{(-0.13)}$ & $\underline{(8.69)}$ & $\underline{(0.85)}$ & $\underline{(4.85)}$ \\
\hline \multirow[t]{2}{*}{$\underline{\text { MNC lat }}$} & $\underline{4.975}$ & $\underline{-0.294}$ & $\underline{1.327}$ & $\underline{3.105} * * *$ \\
\hline & $\underline{(1.10)}$ & $(-0.20)$ & $\underline{(0.33)}$ & (3.62) \\
\hline \multirow[t]{2}{*}{ Experience } & & $\underline{-0.003}$ & & $\underline{0.003}$ \\
\hline & & $\underline{(-0.31)}$ & & $\underline{(0.49)}$ \\
\hline \multirow[t]{2}{*}{ Innovation } & $\underline{0.157}$ & $\underline{0.095}$ ** & $\underline{0.187}$ & $\underline{0.018}$ \\
\hline & $(0.92)$ & $\underline{(2.46)}$ & (1.13) & $(0.88)$ \\
\hline \multirow[t]{2}{*}{ Export } & $1.48 \mathrm{E}-05 * *$ & $\underline{-1.01 \mathrm{E}-06}$ & $1.08 \mathrm{E}-05_{-}^{*}$ & $\underline{-2.52 \mathrm{E}-07}$ \\
\hline & $\underline{(2.57)}$ & $(-0.91)$ & $\underline{(1.96)}$ & $(-0.44)$ \\
\hline \multirow[t]{2}{*}{ Development } & $\underline{0.003}$ & -0.001 & $\underline{0.005}$ & $\underline{-0.000}$ \\
\hline & $\underline{(0.70)}$ & $(-0.54)$ & $\underline{(1.14)}$ & $\underline{(-0.04)}$ \\
\hline \multirow[t]{2}{*}{ North } & $\underline{0.229}$ & $\underline{0.037}$ & $\underline{0.179}$ & $\underline{0.023}$ \\
\hline & $(0.94)$ & $(0.32)$ & $(0.74)$ & $(0.38)$ \\
\hline \multirow[t]{2}{*}{$\underline{\text { Advanced }}$} & $\underline{1.126} * * * *$ & $\underline{-0.306} * *$ & $\underline{0.403}$ & $\underline{0.036}$ \\
\hline & $\underline{(2.77)}$ & $\underline{(-2.01)}$ & $\underline{(1.11)}$ & $\underline{(0.44)}$ \\
\hline \multirow[t]{2}{*}{ Made in Italy } & $\underline{0.758} * *$ & $\underline{0.009}$ & $\underline{0.503} *$ & $\underline{0.082}$ \\
\hline & $\underline{(2.49)}$ & $\underline{(0.06)}$ & $\underline{(1.68)}$ & $\underline{(1.06)}$ \\
\hline \multirow[t]{2}{*}{$\underline{\text { Sigma }}$} & & $\underline{0.392} * * *$ & & $\underline{0.197}$ **** \\
\hline & & $\underline{(13.93)}$ & & $\underline{(13.04)}$ \\
\hline No. obs. & $\underline{199}$ & $\underline{97}$ & $\underline{199}$ & $\underline{85}$ \\
\hline No. Dependent $=1$ & $\underline{97}$ & & $\underline{85}$ & \\
\hline Log likelihood & $\underline{-98.033}$ & $\underline{-46.761}$ & $\underline{-107.393}$ & $\underline{17.262}$ \\
\hline LR statistic & $\underline{79.68}$ & & $\underline{56.85}$ & \\
\hline Pseudo R-squared & $\underline{0.289}$ & & & \\
\hline$\underline{\text { Wald chi } 2}$ & & $\underline{142.07} * * * *$ & & $\underline{101.89} * * *$ \\
\hline
\end{tabular}

Legenda: the asterisks denote the significance of the coefficients estimates: ***:p<.01; **: $\mathrm{p}<.05 ;{ }^{*} \mathrm{p}<.10$ 
Figure. 1 - Dispersion of the degree of internationalisation of industrial districts

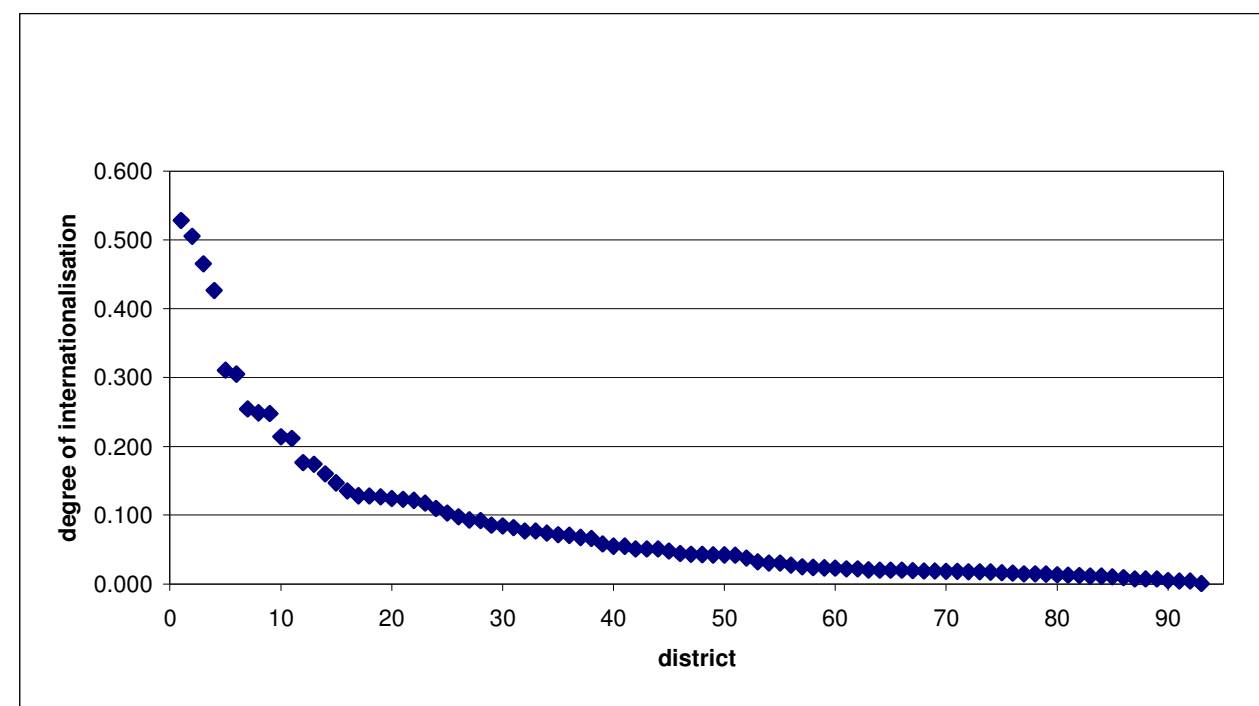

Formatted: English U.K. 